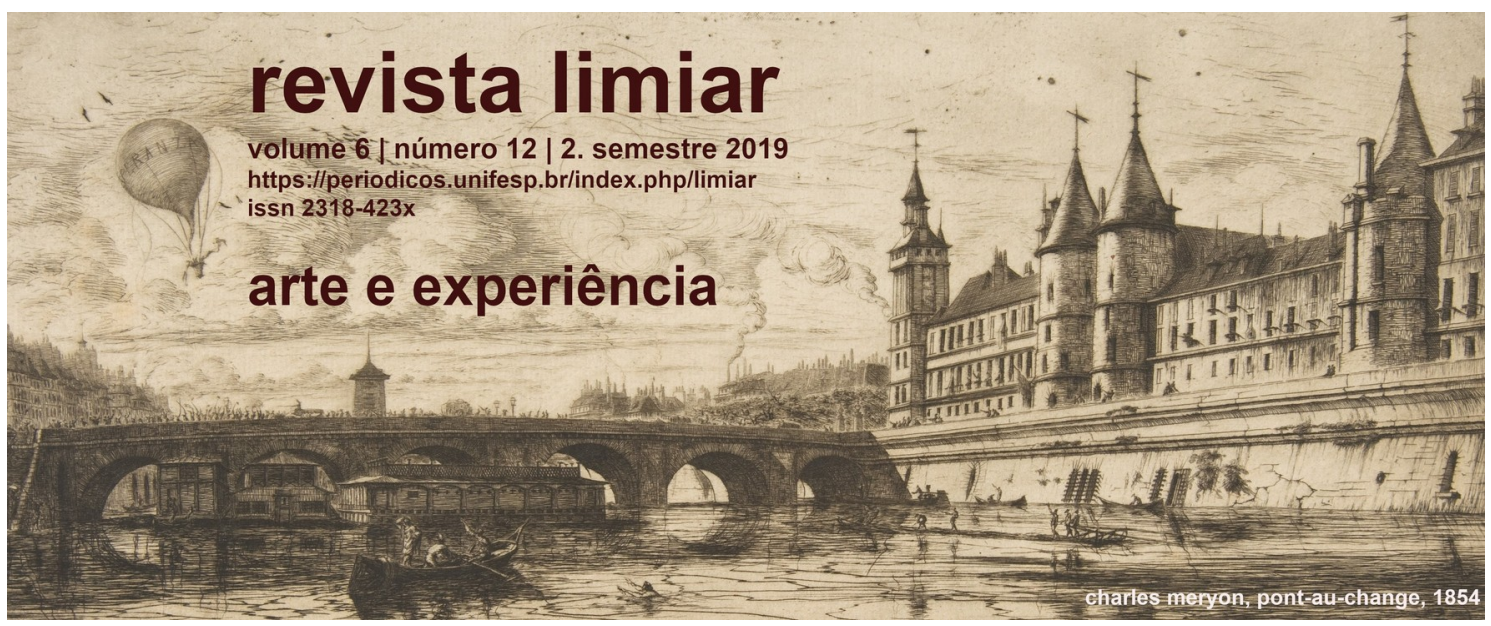

\title{
A experiência literária em $O$ Caminhão, de Marguerite Duras: questões sobre a cultura e a arte
}

\section{Lara Rodrigues Silva*}

Resumo: Segundo Maurice Blanchot as conjunturas históricas influenciam os movimentos artísticos e acabam por lhes darem forma. O autor observa que a literatura (as artes em geral) caminha rumo ao seu desaparecimento. Segundo o escritor, o que verdadeiramente importa na arte é a experiência: o exercício de buscar a obra e, por esse meio, torná-la possível como uma paixão inútil fora da excelência de um poder e de um objeto de uso, numa contemplação que se basta, direcionada, unicamente, ao seu próprio fim. À vista disso, Marguerite Duras escreve, produz e dirige, em 1977, a obra, livro e filme (ou livro/filme) O caminhão, que atravessa a experiência noturna própria da arte, possibilitando, desse modo, pensar em questões pertinentes às relações entre a cultura e a arte.

Palavras-chave: Escrita - Experiência Literária - Desobramento - Cultura - Arte.

Abstract: According to Maurice Blanchot, historical conjectures influences artistic movements and defines their forms. The author observes literature (and arts, in general) in the way to its disappearance. The writer also considers that, in art, what truly matters is experience: the exercise of searching work and, by doing that, make it possible like a useless passion out of the excellence of a power and a usefull object, in a contemplation which is enough and directed to itself purpose. Therefore, in 1977, Maguerite Dure wrote, produced and directed the work, book and movie (book/movie) "Le Camion" ("The Lorry"), that tells the nightly experience of art itself, making it possible to think of relevant questions about the intersection between culture and art Keywords: Writing - Literary Experience - Désoeuvrement - Culture - Art.

\footnotetext{
* Mestra em Estudos Literários pela Universidade Federal de Uberlândia. E-mail para contato: lararodriguess15@gmail.com
} 
Maurice Blanchot afirma que as conjunturas históricas influenciam os movimentos artísticos e acabam por lhes darem forma ${ }^{1}$. Por isso, numa contemporaneidade que se volta a resgatar lições sombrias do passado, não para recusá-las, mas para colocá-las novamente em exercício, por meio de uma releitura talvez mais cruel (se é que se possa estabelecer graus de intensidade à crueldade), pensar a direção em que a arte, a literatura, o cinema se deslocam torna-se um exercício obscuro. Sobre esse deslocamento, Maurice Blanchot vai pontuar, voltandose, mais especificamente, ao campo literário, que a literatura caminha rumo ao seu desaparecimento. A afirmação abrange, aqui, as artes em geral.

Blanchot lamenta a glorificação que se dispende ao artista e não à obra. Isto, para o pensador, enfatiza o afastamento da arte de sua "potência própria" e a sua decadência - "A arte só está próxima do absoluto no passado, e é apenas no museu que ela ainda tem valor e poder. Ou então, desgraça ainda mais grave, ela decai em nós até tornar-se simples prazer estético, ou auxiliar da cultura"2. Em O espaço literário, o pensador explicita que o absoluto passou, atualmente, ao trabalho da história, de modo que toda a legitimidade que a arte possuía, foi apropriada pelo mundo e pelo "trabalho real no mundo"3.

O autor reclama que na arte hodierna ressaltam-se "as experiências subjetivas ou uma dependência da estética"4, enquanto o que verdadeiramente importa é a experiência: o exercício de buscar a obra e, por esse meio, torná-la possível. Mas a obra por vir, a que o artista persegue, segundo Blanchot, por vezes é tomada como "uma atividade e não uma paixão inútil, desejam vê-la colaborar na obra humana em geral [...] e num lugar intemporal, fora do mundo, mas aqui e agora, segundo os limites que são os nossos". Entretanto, esta visão dirigida à obra é impertinente, visto que o que se procura alcançar por meio dela está fora da excelência de um poder, está fora de um objeto de uso, numa contemplação que se basta e que "não remeterá para nenhuma outra coisa, será o seu próprio fim." 5 .

A obra O caminhão (1977), de Marguerite Duras, vem como um auxílo para se refletir acerca das questões pertinentes à arte e à cultura, haja vistaoque a literatura e

1 Cf. BLANCHOT, Maurice. O livro por vir. Trad. Leyla Perrone-MoisésSão Paulo: Martins Fontes, 2005.

2 BLANCHOT. O livro por vir. p. 286.

3 BLANCHOT, Maurice. O espaço literário. Trad. Álvaro Cabral. Rio de Janeiro: Rocco, 2011, p. 233.

4 BLANCHOT, Maurice. O livro por vir. p. 291.

5 BLANCHOT, Maurice. O espaço literário. p. 229-30. 
o cinema durasiano carregam em si uma passagem de vida. Sempre inacabados, perpassam o vivido e o vivível, sendo, dessa forma, inseparáveis de um devir. Não é, todavia, um devir-homem, não demonstra dominância ou imposição ao outro, contudo, como o devir-mulher, animal ou molécula, apresenta um gozo a mais, sem qualquer significante de poder. Ou seja, são devires não pertencentes ao centro e que buscam uma língua sem impostura, nova - sua representação não acontece por meio da identificação, da imitação ou da Mimese, mas de uma desterritorialização absoluta, conforme Gilles Deleuze ressalta em sua obra, Crítica e Clínica. Essa escrita descentrada é um delírio que passa "pelos povos, pelas raças e tribos" ${ }^{6}$ ocupando a história universal.

Desse modo, por meio das reflexões de cunho político presentes em $O$ caminhão, de Marguerite Duras, refletir-se-á acerca de "todos os homens [que] não escrevem", porque não conseguem duvidar - enquanto a escrita vem da desconfiança. Objetiva-se, do mesmo modo, uma volta ao texto como matéria de esquecimento e, daí, sobre o fracasso da escrita, do cinema e do mundo. Do mesmo modo pretende-se discorrer acerca da impossibilidade da revolução cuja única política que se torna viável é a de que, conforme Marguerite Duras, o mundo se arruíne - "Que le monde aille à saperte, c'est la seule politique"7.

\section{O percurso criativo de Marguerite Duras}

Marguerite Duras, apesar de ter as suas obras traduzidas em mais de quarenta países, não é, principalmente como cineasta, muito conhecida ou difundida, seja no meio acadêmico, seja em grupos alternativos em que o cinema seja foco de análise. No Brasil, atualmente a artista é pouco editada ${ }^{8}$ - seus romances, no país, são, comumente, catalogados como romances sentimentais - e seus filmes ${ }^{9}$ foram exibidos apenas em pequenas mostras cinematográficas, sendo conhecidos, assim, de forma autônoma, por círculos específicos que estudam ou procuram um cinema que saia do establishment. O motivo maior desse apagamento deve-se ao modo como a artista

6 DELEUZE, Gilles. Crítica e Clínica. Trad. Peter Pál Pelbart. São Paulo: Editora 34, 2011.

7 DURAS, Marguerite. Le Camion. Paris: Les Éditions de Minuit, 2017, p. 25.

8 As obras de Marguerite Duras foram bastante editadas no Brasil, em sua maioria pela editora Record, durante as décadas de 80 e 90 . Atualmente, algumas obras começaram a ser traduzidas e editadas no país, como o Barragem contra o pacífico (2003), pela editora Arx. Outros livros foram reeditados, como $O$ homem sentado no corredor, A doença da morte (2007) e O amante (2012), pela Ed. Cosac Naify. Suas obras são, contudo, encontradas em sebos, nos virtuais e nas lojas físicas.

9 É possível encontrar os filmes dirigidos por Marguerite Duras na plataforma de downloads Making.off.org., com suas respectivas legendas em português. 
abarca em suas obras as concepções de cultura e arte. É notória a maneira como o sistema capitalista conseguiu transformar a arte em um bem de consumo sem essência, uma mercadoria rígida. A realizadora, contudo, contrapõe-se à lógica mercadológica e se propõe a pensar o ato de fazer filmes de uma forma que se distancia até mesmo do que já havia sido realizado pelo cinema autoral.

Marguerite Duras trabalhou, invariavelmente, com orçamentos minúsculos, pois, para ela, era preferível apresentar um pequeno filme em um espaço diminuto e vender uma quantidade ínfima de ingressos a lançar filmes exuberantes que a cercasse de compromissos e a distanciasse do cinema em si. Isso porque as suas intenções estavam em não se deixar moldar pelas formas preexistentes e sempre fazer isso de maneira reflexiva, questionando, a todo tempo, a indústria cinematográfica. A artista reclama, por exemplo, que os profissionais do cinema perderam a noção da "necessidade" em que se deve pautar a feitura dos filmes. Conforme a autora, o cinema é um dispositivo de conhecimento e esse deveria ser o único modo de abordá-lo.

Em seu texto "Fazer cinema", presente em Os olhos verdes, a artista afirma: "Não sei se encontrei o cinema. Fiz cinema. Para os profissionais, o cinema que faço não existe."10. O não reconhecimento de Marguerite Duras como cineasta decorre da estranheza causada por suas obras ao abdicar do entretenimento por si só e procurar, sempre, subverter a ordem daquilo que é a essência do filme: o texto, a imagem, a voz. ${ }^{11}$

O não reconhecimento do cinema durasiano por parte de outros realizadores acontece, entre todas as peculiaridades de sua forma de abordar o universo fílmico, também pelo fato da artista não considerar o cinema e a escrita um trabalho. Ao menos não nos termos capitalistas. Segundo Marguerite Duras, escrever - e ela afirma estar falando da escrita mesmo quando está dizendo do cinema - "é atingir o não-trabalho". Criação para a autora é uma "relação de forças", é poder governar

10 DURAS, Marguerite. Os olhos verdes. Crônicas publicadas em Cahiers du Cinéma. Trad. Heloisa Jahn. Rio de Janeiro: O Globo, 1988, p. 46.

11 "Há no cinema, no mundo do cinema, uma enorme pretensão que não existe no mundo literário, é preciso que se diga. No cinema você encontra... o mais ínfimo dos sujeitos que fez um filme lhe diz: ' $O$ que você faz não é cinema'. Então eu pergunto: 'O que é o cinema? ' $E$ me dizem 'É outra coisa, tem mais ação.' 'Então, o cinema por excelência é o faroeste? É o que mais se mexe.' Então me dizem: 'Você não entendeu o cinema. Não é isso que queremos dizer.' E quando digo que uma palavra se mexe tanto quanto um braço, ou que um olhar se mexe tanto quanto um cavalo, que um olhar que se desloca bem vale um deslocamento de uma máquina, eles não entendem." Cf. DURAS, Marguerite, GAUTHIER, Xavière. Boas falas: Conversas sem compromissos. Rio de Janeiro: Editora Record, 1974, 69. 
aquilo que lhe chega subitamente antes que se perca para sempre - é "desobstruir-se de si" e se colocar num anonimato para o próprio "eu" 12.

Marguerite Duras considera o instante da feitura do livro - leia-se o filme também - inviolável, por isso, solitário. Se este momento é interrompido, corre-se o perigo de a escrita não acontecer. De modo que permitir que um livro e/ou filme saia de si é saber que algo de seu interior, do mesmo modo, se externa e se perde definitivamente. O processo de feitura da obra, para a autora, é "vida em potência de existir, e, como a vida, tem necessidade de todos os constrangimentos, de sufocação, de dor, de lentidão, de sofrimento, de entraves de todo tipo, de silêncio e de noite". O primeiro momento do livro/filme, conforme a realizadora, "passa pelo desgosto de nascer, pelo horror de crescer, de ver o dia"13, o que requer coragem e força do escritor para suportar esse transcurso, pois é necessário saber e aceitar, de forma absolutamente só, que ao chegar ao exterior um mistério, desconhecido pelo escritor, espera o livro cujo destino é incerto. Desse modo, é preciso que o artista não mutile o por vir de sua obra.

Ao fazer cinema, Marguerite Duras afirma que está, do mesmo modo, a escrever sobre a imagem: a refletir sobre sua natureza e sua significação, de modo que a escolha da imagem, ou a produção do filme, seja o resultado dessa escrita. Essa interação que Marguerite Duras estabelece entre escrita e cinema vem de uma relação de "assassinato com o cinema", cujo objetivo maior foi, a princípio, o de "atingir a experiência criadora da destruição do texto". Contudo, esse desejo da cineasta desloca-se à imagem - pretende-se, agora, reduzi-la ao ponto de se chegar a uma imagem-chave, "que possa ser indefinidamente sobreposta a uma série de textos, imagem que não teria nenhum sentido em si, que não seria nem bonita nem feia, que só assumiria um sentido a partir do texto que sobre ela passasse". Duras justifica que o excesso imagético no cinema é desnecessário, não leva a nada; com um filme preto, entretanto, ela chegaria "à imagem ideal, à do assassinato confesso do cinema"14.

Seria precário, dessa forma, a tentativa de elaborar sínteses dos filmes de Marguerite Duras, pois são obras cheias do feminino, de vazios, que apenas atravessam, como as vozes ali presentes. Na linguagem utilizada, "a palavra é mais importante que a sintaxe. São antes de mais nada as palavras, sem artigos, aliás, que

12 DURAS, Marguerite. Os olhos verdes. p. 24.

13 DURAS, Marguerite. Os olhos verdes. p. 90.

14 DURAS, Marguerite. Os olhos verdes. p. 91. 
vêm e se impõem. O tempo gramatical segue-as bem de longe"15. Outro aspecto desse cinema são as faltas, propositais, de tomadas a situarem o espectador sobre os acontecimentos do filme. Isso se dá a fim de que a relação do público com a obra não seja de total passividade ${ }^{16}$.

Marguerite Duras quer evitar em suas obras "uma relação como que balzaquiana" em que "tudo é digerido. Entregam-lhe [ao espectador], ele deglute, ou então vomita"17. Por isso, em O caminhão, filmado em 1977, o primeiro caminho encontrado para a feitura da obra é o da voz, o da leitura. Marguerite Duras ressalta que não se busca com a leitura aprofundar-se nos sentidos do texto, mas em seu primeiro estado, sua primitividade - sendo isso o significado da frase: "experiência criadora da destruição do texto". A leitura, então, por si só, estabelecerá o sentido - ou o que se propõe verdadeiramente, ou seja, a frase por vir, a forma aberta, o lugar vazio, as palavras reduzidas a pó, a imagem.

No intuito, então, de demonstrar como se estrutura $O$ caminhão, abre-se, aqui, um espaço denominado "O CAMINHÃO (1977) - Os textos de apresentação" - a fim de mapear os territórios que demarcam o livro: o texto em si, os "Textos de apresentação" - em que a autora discorre acerca dos quatro projetos sobre os quais a história é fundada - e a entrevista com Michelle Porte, todos compondo a publicação original do livro. Do mesmo modo, a partir do tópico "Um caminhão que se borda em ponto de escrita: da obra literária e cinematográfica", são elaboradas algumas reflexões tanto sobre o texto quanto sobre o filme, seguindo o fio das conversas de Duras e Porte na "Entrevista com Michelle Porte", presente no final do livro. Devido aos limites textuais impostos pelo gênero do artigo, que aqui se escreve, os textos de apresentação serão introduzidos sem a realização de análises mais profundas.

\section{O CAMINHÃO - Os Textos de Apresentação}

O livro O caminhão é dividido em três partes. Na primeira há o texto literário/cinematográfico propriamente dito, ao término desta, os "Textos de

15 DURAS; GAUTHIER. Boas falas: p. 91.

16 "(...) talvez seja porque [as faltas de tomadas] acompanham a escrita. Eu escrevo, por exemplo, em Nathalie Granger, quando a mulher vai buscar o jornal, a carta e os blocos de anotações, eu escrevo: 'pega o jornal', parágrafo, 'rasga', parágrafo, 'rasga mais'. É um exemplo. Não escrevo: 'dá três passos, pega, levanta, olha e em seguida rasga o jornal e uma vez...' Entende? Então fica: 'pega o jornal', parágrafo, 'rasga', não há intermediário. Então talvez seja porque isso se segue, talvez não seja bem uma escrita de cinema. Mas será que existe uma escrita de cinema? Quem pode dizer que sabe?". DURAS; GAUTHIER. Boas falas, p 68.

17 DURAS; GAUTHIER. Boas falas. p. 68. 
Apresentação" - em que são introduzidos "Quatro Projetos" sobre o fim do cinema - e que são, também, uma síntese do que se trata a obra -, e, por último, uma entrevista com Michelle Porte.

\section{Primeiro projeto - A perda do cinema é a sua única política}

No "Primeiro projeto", Marguerite Duras afirma só valer a pena fazer cinema sobre a alegria, pois todos os demais temas fracassaram: a esperança socialista, a justiça por vir, o trabalho, o mérito, as mulheres, os jovens, os intelectuais, a ditadura do proletariado, o amor, o sofrimento, a revolução - tudo isso esgotou-se, são ruínas. Dos escombros disso, de que não vale mais a pena fazer cinema surge, por exemplo, a descrença, ou seja, não se crê em mais nada que não seja na alegria. Porque a alegria é exterior, considera o todo, e seu fracasso é a única política válida, porque, daí, pode-se recomeçar novas utopias, novas formas de amor.

A Primavera de 1968, ocorrida na França, é, para Marguerite Duras, o maior exemplo de que a perda é a única política do mundo de que se compensa falar. Em maio de 1968, um movimento de estudantes, rebelando-se contra o conservadorismo dos costumes, iniciou uma onda de protestos que se alastrou por toda Europa, embora tenha começado, e ocorrido mais fortemente, na França, resultando em uma grande greve do proletariado reivindicando seus direitos. Embora materialmente não se tenha conquistado grandes coisas, em termos de ideais de esquerda, no que tange às ideias progressistas e de direitos humanos, foi um grande passo à frente. $E$, de acordo com Marguerite Duras, o fracasso desse evento político é o ponto do qual se precisa falar, porque daí vem a alegria de se ter as grandes convicções, a utopia, disseminadas ${ }^{18}$.

O caminhão não é, portanto, uma obra política, mas se realiza a partir de um ponto de vista político. É pela feitura dessa obra que Marguerite Duras se sente livre do medo e passa a falar livremente das coisas em geral - da política, sobretudo. Segundo a autora, essa libertação do medo equivale à perda da fé, ela diz: "não tenho mais medo de que me tachem de anticomunista. O famoso ditado stalinista 'se não estás conosco, estás com eles' acabou, e de agora em diante me faz rir” ${ }^{19}$. Da mesma

18 "Os pobres de espírito, os de alma mesquinha, os espíritos sem generosidade dizem: 'O ano de 68 não deu resultado, portanto foi um fracasso', e 68 ainda está subsistindo, completamente, é uma aquisição total, inteiramente positiva, mesmo que tenha fracassado. O Chile é inteiramente positivo, mesmo que tenha terminado em sangue". Cf. DURAS. O caminhão. Rio de Janeiro: Editora Record, 1977. p. 37.

19 DURAS. O caminhão. p. 89. 
forma como ri, com alegria, em determinada parte de $O$ caminhão, a mulher, quando 0 motorista a chama de reacionária e, diante de sua reação, insinua ser louca ${ }^{20}$.

O caminhão é fiel a esse primeiro projeto. A alegria é sua (a)bordagem constante. Quando o motorista questiona a mulher se ela "faz política", a resposta que recebe da senhora é que não, não faz e que nunca fez nada nesse sentido. Porém, isso é dito alegremente, por meio da certeza de que é por meio das perdas, dos fracassos, da expressão "não deu em nada" - como é atribuída constantemente à Primavera de 1968 - que o que verdadeiramente importa se realiza: alastram-se as ideias, tornam-se potentes as utopias.

\section{Segundo projeto - 0 excesso imagético}

Neste espaço, Marguerite Duras discorre acerca dos filmes que, excessivamente imagéticos, apresentam-se como uma prisão do imaginário. Ela ressalta a necessidade de morte das realizações do cinema convencional. A artista deseja e, segundo sua opinião, os espectadores também, um cinema aberto, cheio de vazios que permitam que ele seja ativo na construção do sentido e não pateticamente passivo, como comumente é o cinema que ilustra histórias ao invés de permitir que a audiência as evoque. Conforme a realizadora, o texto sim é capaz de abrir o imaginário por carregar uma gama ilimitada de imagens, ao contrário do cinema - seja ele qual for, experimental ou comercial.

Peter Greenaway (2001), no ensaio "105 anos de cinema ilustrado" tece, tal qual Marguerite Duras, críticas pontuais ao cinema que apenas ilustra histórias literárias. O cineasta condena esse modo de fazer filme em que os diretores só fazem seguir o texto "muitas vezes nem criando imagens, mas apenas segurando a câmera enquanto ela executa a sua mais reles mímese." ${ }^{21}$. Greenaway questiona a existência desse cinema que necessita, imprescindivelmente, do texto para existir - ao contrário da crítica durasiana voltada ao seu excesso imagético. O ponto de tangência entre os teóricos acontece ao compararem a potencialidade imaginária cinematográfica com a da literatura. $O$ texto literário por si só abre o imaginário quando se lê. Como o cineasta exemplifica em seu artigo, na frase "'ele entrou na sala", existe uma abertura que possibilita ao leitor evocar inúmeros modos encenação; no "cinema-como-o-

20 "G.D.: Que pensa ele? Que diz ele? / M.D.: Ele diz: compreendi. / A senhora é uma reacionária. / G.D.: Ela responde o quê? / M.D.: Nada. Ela ri. / (Sorrisos. Silêncio.) / M.D.: Então, ele diz: compreendi. A senhora é uma fugitiva do asilo psiquiátrico de Gouchy." DURAS. O Caminhão. p. 37.

21 GREENAWAY, Peter. Cinema: 105 anos de texto ilustrado. In: O cinema enciclopédico de Peter Greenaway. São Paulo: Unimarco editora, 2004, p. 11. 
conhecemos", porém, se se "vê" tal enunciado encenado, o espectador estará limitado apenas a demonstração realizada na tela de cinema.

Portanto, sabendo-se um deserto de si mesmo, o cinema luta para reencontrar o seu espectador a partir de realizações bilionárias, porém, inutilmente: o desejo de conhecimento do espectador está para além disso. Devem compreender, aqueles que fazem cinema, que "a fabricação do filme já é o filme" ${ }^{22}$. Ou seja, o filme é um processo, não é o seu fim e O caminhão comprova o argumento por ser uma obra que ocorre a partir do instante de sua feitura - do seu vir-a-ser. Assim, a recusa do espectador está, do mesmo modo, no excesso de palavras de ordem desse cinemaproduto. O espectador, totalmente passivo nesse processo, é, também, solitário. Não há um eco de seus desejos, de sua voz na tela que passa o filme. Dessa forma, o espectador mais voraz já abandonou o cinema - não conseguiu suportar a falta de noite nas projeções atuais.

\section{Terceiro projeto - A não-representação}

Aqui, Marguerite Duras (1977) vai tratar da não-representação, em termos miméticos, da mulher, personagem de $O$ caminhão. A artista também devaneia sobre a falta de destino d'O caminhão: "Não sei aonde vou em O caminhão. Ela, a mulher, também não sabe"23. Duras desconhece, inclusive, essa mulher. O que a artista consegue visualizar é uma mulher na curva de uma estrada. Assim, impessoal, indefinidas: uma mulher, uma estrada. Dessa forma, a autora não trabalha no texto que daria a direção ao filme antes que esse fosse realizado, pois ambos, o texto e a mulher, aconteceriam no decorrer do filme - eles seriam a película; antes do acontecimento fílmico, apenas a espera seria viável. A artista e a mulher estão sempre olhando o exterior, o fora. A autora, por amá-la, consegue vê-la; ela, por sua vez, que não se sabe amada (nem que o pode ser) não se vira para olhar a autora - fixa seu olhar no exterior, sempre. A realizadora, olha, então, o que ela encara e, assim, nunca vê o rosto da mulher; entretanto, consegue enxergar e deslumbrar-se com aquilo que a mulher olha: o filme.

\section{Quarto projeto - O amor de "ordem geral"}

Já no "Quarto Projeto", Marguerite Duras relata que o pretexto para se falar de amor, como fizera em seu filme India song (1975), já não existe em O caminhão. Pois 
há uma perda de identidade muito forte na mulher, sua anulação é tamanha que o amor que vive é de "ordem geral", exterior e totalmente ignorado por ela. A mulher é alegre em sua existência que não carece de sentido. Apenas vive em um constante estado de "espera dela mesma, na esperança de ser tudo ao mesmo tempo"24. 0 deslocamento dessa mulher em "direção ao tudo" é, para Marguerite Duras, o próprio movimento do amor, pois não necessita de nenhum reconhecimento ou sentido; apenas vive em sua alegria - mais nada.

\section{Entrevista com Michelle Porte}

No diálogo com Michelle Porte, Marguerite Duras conta os processos de produção do filme, os fracassos e acertos e como nasceu, enfim, a obra. Ademais, as duas mulheres conversam sobre as escolhas feitas para se obter o efeito que a artista desejava para esse filme por vir, além de refletirem acerca do cinema, desde sua criação como gênero, e de aspectos do acervo fílmico produzido por Duras.

\section{Um caminhão que se borda em ponto de escrita: da obra literária e cinematográfica}

A produção de $O$ caminhão passou por três etapas: a primeira consistiu na busca por uma atriz. Pensou-se em Simone Signore e Suzanne Flon; no entanto, ambas estavam indisponíveis. Num segundo momento, Duras cogitou fazer ela mesma a personagem feminina, mas desistiu dessa produção devido ao frio de janeiro que impossibilitava a filmagem na cabine do caminhão. Assim, em uma noite de insônia, Marguerite Duras encontrou uma solução: em vez de produzir um filme, iria contá-lo. Isto é, iria revelar como seria o filme, caso fosse produzi-lo. Dessa forma, a autora convidou um amigo, o ator Gérard Depardieu, e ambos leram o texto em uma sala (denominada câmara escura ou câmara de leitura) ${ }^{25}$.

Seguem algumas imagens do filme a fim de ilustrar a maneira como foi filmado:

24 DURAS. O caminhão. p. 63.

25 "O filme é lido com as folhas nas mãos e, para Depardieu, é lido pela primeira vez, e a atenção que ele dedica à leitura é vista no filme. Aliás, eu digo no filme: 'Nenhum ensaio do texto foi previsto.' Acho agora que isso foi para evitar interpretação. Se tivéssemos lido o texto antes, se o tivéssemos ensaiado, mesmo para lê-lo em seguida, teríamos interpretado. Às vezes há alguns erros de pronúncia, trocamos as frases, as procuramos, mas era uma opção, e preferi isso a uma distância entre o texto e a pessoa que fala e que eu chamo a comédia. Mas não percebi isso logo do começo, é agora que eu sei, que eu compreendo o porquê da frase no ensaio. É por isso também que não posso considerar entregar o texto a um ator teatral: ele seria obrigado a aprendê-lo, e portanto representá-lo. Uma leitura rápida, uma primeira leitura rápida, com as folhas na mão, é tão cinema se não mais, que interpretação do conteúdo dessa leitura ou representação." DURAS. O caminhão. p. 68-69. 
Figura 1: Travellinad'o Caminhão

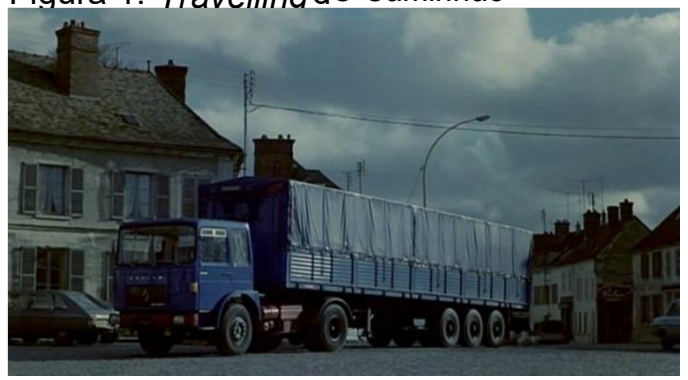

Fonte: makingoff.org _ Screenshots

Figura 3: Câmara escura - M. Duras

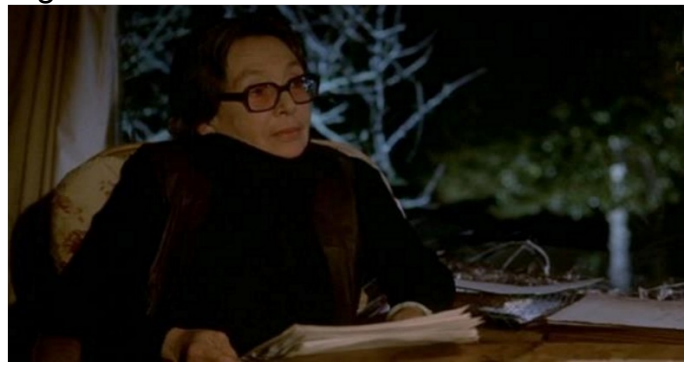

Fonte: makingoff.org - Screenshots

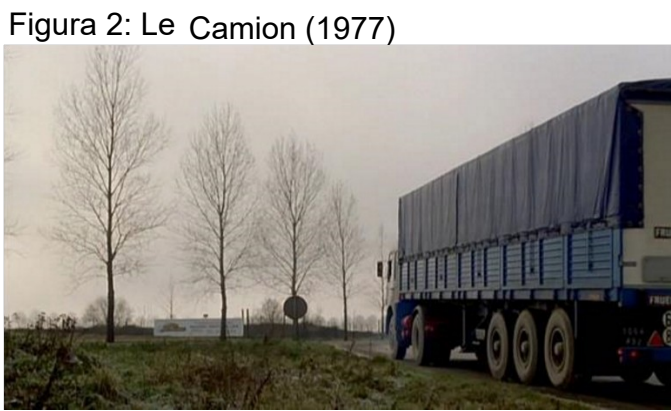

Fonte: makingoff.org Screenshots

Figura 4: Câmara escūra - G. Depardieu

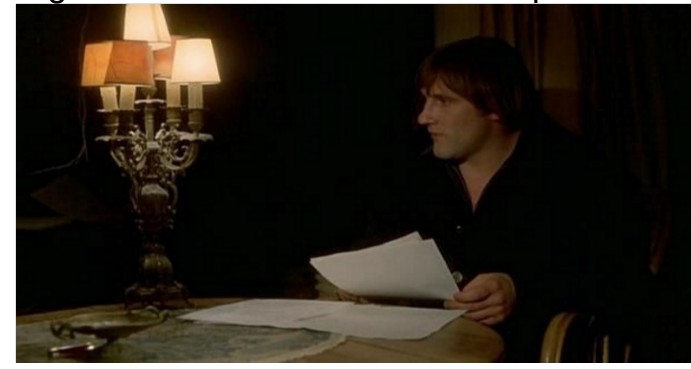

Fonte: makingoff.org - Screenshots

A montagem da película é realizada alternando cortes entre a passagem do caminhão pelas estradas de Yveline, como ilustram as figuras 1 e 2, e a leitura na "câmara escura", figuras 3 e 4. O texto lido por Duras e Depardieu, como ilustram as duas últimas imagens, é a conversa entre um homem, motorista de um caminhão, que dá carona a uma mulher de certa idade - ambos não "aparecem" no filme, ou seja, não são representados por atores, suas imagens são evocadas pelas vozes de Duras e Depardieu. Nos momentos em que há cortes para os travellings do caminhão, ouvese a voz de Marguerite Duras em off ou a trilha sonora - ou ambas - composta por variações de Beethoven sobre um tema de Diabelli, intepretadas por Pascal Rogé.

A realizadora toma $O$ caminhão como o filme que não será feito. Indo em direção ao que Deleuze afirma acerca do inacabamento da literatura, a obra aqui em foco caminha para um devir "sempre inacabado, sempre em via de fazer-se" ${ }^{26}$. Podese lê-la, igualmente, pelo pensamento de Maurice Blanchot (2005), para quem a literatura está em um aquém e em um além da linguagem - num por vir - numa escrita de passagem, de travessia. Isto porque Marguerite Duras, mesmo ao falar de cinema, direciona-se sempre à escrita - o que é ressaltado no texto "Solidão", presente em Os olhos verdes ${ }^{27}$.

26 DELEUZE. Crítica e Clínica. p. 11. 
Dessa forma, enfatiza-se que as obras literária e cinematográfica d'O caminhão, estruturam-se a partir da confluência entre texto e imagem - ou seja, o limite da escrita desemboca no limite do cinema e vice-versa. Ressalta-se, também, que, apesar de aludir a um caráter roteirístico, a escrita de $O$ Caminhão será denominada, aqui, "texto" e não "roteiro". Tal escolha justifica-se pelo caráter dos escritos durasianos, cuja maior pretensão é a de encontrar o estado primitivo do texto "assim como a gente tenta se lembrar de um acontecimento longínquo, não vivido mas 'ouvido dizer'. [...] o lugar de uma frase ainda por vir." Isto é, como explicitado por Marguerite Duras, o roteiro evoca um "depois", um destino, um objetivo, enquanto o que se busca atingir com o seu cinema é, ressaltando o que já foi dito, "a experiência criadora da destruição do texto" e a redução das imagens a uma imagem-chave - "à imagem ideal, à do assassinato do cinema"28.

Duras afirma existir nessa obra cinematográfica uma função de fio - é a origem de muitos filmes que ela poderia fazer: "esse filme que não farei, quando falo dele, contém os outros filmes, e foi isso que descobri. Ele contém todos os outros filmes que eu poderia fazer a partir dessa ideia que é muito vulgar", já bastante empregada, e de modo espetacularizado, pelo "mundo inteiro" - o caminhão. O tema, segundo a autora, "foi usado de maneira realista em todos os lados, na América, na França, em todos os lugares; ultimamente houve um filme na televisão que se passava num caminhão, no seu interior, com uma plataforma de filmagem". ${ }^{29}$ A obra durasiana, como um todo, tal qual a colcha de Penélope, funde-se ao que Ruth Silviano Brandão (2006) define como frivolitê - um ponto de crochê que sua mãe fazia "interminavelmente". São fios que se enroscam a outros fios - muitas vezes os de outrem, mas sempre tecendo uma rede com seus escritos sempre em estado de devir, matérias de memória. 0 caminhão irrompe, então, convergindo todos os escritos e filmes já realizados por Duras nesse por vir incessante que é a escrita de uma obra. ${ }^{30}$

27 "Falo da escrita. Falo também da escrita até quando dou a impressão de estar falando de cinema. Não sei falar de outra coisa. Quando faço cinema escrevo, escrevo sobre a imagem, sobre aquilo que ela deveria representar, sobre minhas dúvidas quanto a sua natureza. Escrevo sobre o sentido que a imagem deveria ter. A escolha da imagem, feita em seguida, é uma consequência dessa escrita. A escrita do filme - para mim - é o cinema. Em princípio um roteiro é feito para 'depois'. Um texto, não. Aqui, quanto a mim, é o oposto." DURAS. Os olhos verdes. p. 91.

28 DURAS. Os olhos verdes. p. 91-92.

29 DURAS. O caminhão. p. 69.

30 "M. P. - [...] num lugar fechado, um homem e uma mulher... a mulher é a senhora... falam durante uma hora e vinte. A mulher conta uma história que é a de uma mulher que sobe num caminhão pedindo carona e que durante uma hora e vinte fala ao motorista que lhe deu carona./ M. D. - ... E que não a ouve. / M. P. - ... E que não a ouve. Essa história a senhora apresenta a Depardieu, que é, portanto, uma espécie de substituto do motorista: o motorista ouvindo a mulher falar a ele, Depardieu, ouvindo a senhora ler a história. / M. D. - Isso mesmo, ele nunca se mexeu. Faço questão de dizer, ele foi sempre, desde o 
A realizadora vai relatar, então, esse filme por vir usando o tempo condicional do modo indicativo, estabelecendo um tom de faz de conta, um futuro hipotético em que a película, de fato, aconteceria, citando, então, como epígrafe do livro, a gramática Grevisse $^{31}$. No artigo intitulado "O cinema sem imagens", Paulo Fonseca Andrade afirma ser o condicional "um tempo agenciador de tempos". Segundo o autor, esse tempo equivale, na língua portuguesa, ao "futuro do pretérito" e, no francês, é chamado, similarmente, "futuro anterior". Tais nomeações vão evidenciar "a tensão entre tempos aparentemente opostos e aponta para a existência de um futuro-nãorealizado-de-um-passado, ou ainda, mais longe, do futuro em potência que habita todo o passado, independente de sua realização." ${ }^{2}$. Esse tempo relaciona-se, particularmente, com os aspectos criativos. Isto é, com a imaginação: a ficção, as brincadeiras infantis, o faz de conta. Assim, as crianças materializam uma realidade de faz de conta em seus jogos ao dizer: "você ia ser um pirata, você é um pirata, você ia ser um caminhão, eles se tornam o caminhão: e o futuro do pretérito é o único tempo que traduz a brincadeira das crianças: total. O cinema deles" ${ }^{\prime 3}$. Marguerite Duras, da mesma forma, ao fazer de conta, junto a Gérard Depardieu, que haveria uma estrada, uma mulher, um homem, um caminhão, uma paisagem - faz cinema, tal qual as crianças em suas brincadeiras. O seu cinema. ${ }^{34}$

Dessa forma, o que se coloca, então, em questão com essa obra é o seu processo de inacabamento. A história é contada no tempo condicional e, quase, na escuridão - porque, segundo a autora, não é possível escrever com a luz diurna, escreve-se sempre à noite - assim, cabe também ao leitor/espectador fechar seus olhos e assistir $O$ caminhão a partir daí. A única via de acesso a essa obra é participando desse faz de conta e decidindo, por si mesmo, nunca o que é, mas o que poderia ter sido esse filme sempre em via de se fazer.

primeiro dia, o motorista ocasional. Seja como for, eu via Depardieu em qualquer parte, dentro ou fora do caminhão. Ele jamais se mexeu. Era preciso." DURAS. O caminhão. p. 69-70.

31 "O condicional propriamente dito exprime um fato eventual ou irreal cuja realização é olhada como consequência de um fato suposto, de uma condição. [...] [É também empregado] para indicar uma simples imaginação, transportando de certa forma os acontecimentos para o campo da ficção (em particular um condicional preparatório, empregado pelas crianças nas suas propostas de brincadeiras)." DURAS. $O$ caminhão. s/p.

32 ANDRADE, Paulo de. O cinema sem imagens. In: Aletria, Revista de Estudos de Literatura, Belo Horizonte, n.8, dez. 2001. (Literatura e cinema). p. 112.

33 DURAS. O caminhão. p. 70. Grifos meus.

34 "Haveria uma estrada à beira mar. / Ela atravessaria um grande planalto descampado. / E depois um caminhão chegaria. / Passaria lentamente pela paisagem. / Há um céu branco, de inverno. / Também uma neblina, muito tênue, espalhada em toda atmosfera pela região". DURAS. O caminhão. p. 8. 


\section{Da experiência literária}

Maguerite Duras observa que escrever é uma solidão que se inicia no corpo, dentro de uma casa vazia, e "transforma-se na outra, inviolável, a solidão da escrita" 35 . Foi em sua primeira solidão que ela descobriu que escrever era o que se deveria fazer. Para Maurice Blanchot essa é a solidão essencial - que não é sinônimo, segundo ele, de recolhimento, pois, "[e]xclui o isolamento complacente do individualismo"36.

Dessa solidão, pontua Blanchot, vem a ignorância do autor com relação ao fato de que a obra é infinita, o que faz com que ele continue a buscá-la - mas fatores sociais como a figura do editor, exemplifica o estudioso, obrigam o escritor a interromper sua tentativa de chegar à obra por meio de um término inexistente - que vai continuar, infinitamente, num encontro com o inacabado. Blanchot ressalta, porém, que "a obra de arte, a obra literária - não é acabada nem inacabada: ela é. O que ela nos diz é exclusivamente isso: que é e nada mais. Fora disso, ela não é nada" ${ }^{37}$. E que, além disso, a solidão da obra não significa incomunicabilidade, ela nunca falta ao leitor, mas o abraça na leitura, como o faz àquele que escreve, durante o momento da criação.

Marguerite Duras afirma que "[a] solidão também quer dizer isso: ou a morte ou o livro"38. Essa solidão da/na obra se dá porque ao autor é autorizado escrever apenas o livro - "um amontoado mudo de palavras estéreis, o que há de mais insignificante no mundo" - não a obra, pois tudo que esta pode lhe oferecer é a sua ausência. Isso torna impossível ao escritor ler o que escreve, já que para si sua obra é ilegível, "um segredo, porque está separado dele" ${ }^{\prime 3}$. Assim, enfatiza-se, só lhe é permitido, então, escrevê-la incessantemente.

Existe também um enigma na impostura causada pela solidão da escrita ao exigir que o autor escolha entre a morte ou o livro e que ele demora a decifrar. Já que, segundo Blanchot, aquele que escreve está morto no momento em que a obra acontece, encerrando-se na impossibilidade de conhecê-la, "em sua ausência, na afirmação impessoal, anônima que ela é - nada mais." ${ }^{40}$. A morte que acontece nesse movimento incessante de escrever vem, igualmente, de um apagamento do "Eu" que

35 DURAS. Escrever. Trad. Rubens Figueiredo. Rio de Janeiro: Rocco, 1994, p. 15.

36 BLANCHOT. O espaço literário. p 11.

37 BLANCHOT. O espaço literário. p 12.

38 DURAS. Escrever. p. 18.

39 BLANCHOT. O espaço literário. p 13-14.

40 BLANCHOT. O espaço literário. p 13. 
se substitui pelo "Ele". Ou seja, a literatura não se faz por uma impostura da "matéria vivível ou vivida" ${ }^{41}$, mas num devir, num processo de eterno inacabamento. Escrever é estabelecer uma passagem ao aquém e ao além da linguagem - retirando-a do centro, isto é, de tudo o que detém um poder e, assim, domina.

Fazer literatura é descentrar-se de si, aceitar o que a escritura retira da sombra interna e esquecer aquilo que é da impostura da língua - o "eu". Ou seja, não (ex)ceder às primeiras pessoas pronominais: às "minhas" lembranças, à "minha" viagem, ao "meu" luto; é retirar-se de uma estrutura edipiana, de uma escrita pai-mãe que infantiliza a literatura (Deleuze). A escrita literária recusa, então, toda forma de coação e apenas acontece a partir do momento que se deixa irromper uma terceira pessoa "que nos destitui do poder de dizer 'eu'" 42.

É preciso, então, que o neutro blanchotiano se instale para que se escreva com sinceridade, a partir de uma língua estrangeira, "que não é outra língua, nem um dialeto regional redescoberto, mas um devir outro da língua, uma minoração dessa língua maior, um delírio que a arrasta, uma linha de feitiçaria que foge ao sistema dominante"43. É necessário, do mesmo modo, que esse delírio se mostre como saúde ao descentrar-se, ao falar "por" (e não em "lugar de") um povo que falta contra "uma raça pura e dominante", a fim de que não se caia no perigo de arrastar a literatura ao facismo que ela tanto recusa e que, segundo Deleuze, está a todo momento alerta para identificá-lo em si mesma e combatê-lo.

Dessa forma, se o escritor decide sustentar o chamamento da escrita, é-lhe tirado o poder de falar em seu nome ou passar a palavra a outro. Só lhe é possível, então, o silêncio, a passividade vinda do desastre, da queda do astro: "Ler, escrever, como se vive sob a sobrevigilância do desastre: exposto à passividade para além da paixão. A exaltação do esquecimento. Não és tu que falarás; deixa o desastre falar em ti, que seja por esquecimento ou por silêncio" ${ }^{4}$. Ler a partir da aceitação de que "a

41 DELEUZE. Crítica e Clínica. p. 11.

42 "[...] por certo, os personagens literários estão perfeitamente individuados, e não são imprecisos nem gerais, mas todos os seus traços individuais os elevam a uma visão que os arrasta num indefinido como um devir potente demais para eles: Ahab e a visão de Moby Dick. De modo algum o Avarento é um tipo, mas, ao contrário, seus traços individuais (amar uma rapariga, etc.) fazem-no chegar a uma visão, ele vê o ouro, de tal maneira que se põe a fugir sobre uma linha de feitiçaria na qual ganha a potência do indefinido - um avarento..., um tanto de ouro, mais ouro... Não há literatura sem fabulação, mas, como Bergson soube vê-lo, a fabulação, a função fabuladora, não consiste em imaginar nem em projetar um eu. Ela atinge sobretudo essas visões, eleva-se até esses devires ou potências." DELEUZE. Crítica e Clínica. 13-4.

43 DELEUZE. Crítica e Clínica. p.16.

44 BLANCHOT. A escrita do desastre: fragmentos caídos de um texto ardente. Trad. João Rocha. In.: Revista Em Tese, v. 21, n. 2. Belo Horizonte: UFMG, Mai. - Ago./2015, p. 149. 
língua faz-se", conforme afirma Maria Gabriela Llansol - "Eu não sei falar sobre a língua, a língua faz-se"45 -, de forma que essa língua se torne matéria, mas sem a imposição linguística ou comunicativa. ${ }^{46}$

No espaço do silêncio habitam, também, aqueles escritores que podem "não escrever", como Joseph Joubert. O autor em questão não deixou nenhum livro, mas deixou uma obra; o que existe em seu nome são cadernos em que escrevia seus pensamentos e foram levados ao público depois de sua morte. Ele não escreveu "para acrescentar um livro a outro, mas para se tornar mestre do ponto de que the parecia sair todos os livros e que, uma vez encontrado, o dispensaria de escrever" ${ }^{\prime \prime}$. Os cadernos de Joubert assemelham-se a diários. E, segundo Blanchot, os diários possuem uma função de borda - são escudos a defender o "eu" contra a loucura - o perigo da escrita ${ }^{48}$.

Não há, todavia, no pensamento de Blanchot acerca de Joseph Joubert um julgamento negativo à não publicação, já que esta é a responsável por levar a obra à luz exterior. Blanchot reconhece a necessidade material da publicação, já que o escritor, como pertencente a uma estrutura social, "precisa daquilo que é de valor, o dinheiro"49.

Maurice Blanchot não trata, portanto, "público", em sua obra, em oposição a "privado" - o vocábulo pertence, então, conforme o autor, ao mesmo campo semântico de "exterior". Marguerite Duras trata disso n'O caminhão. Para a autora, a câmara escura em que ela e o ator Gérard Depardieu fazem a leitura indica o "interior" (já convertido ao fora da vida vivida), o movimento das vozes, a exigência da obra em acontecer. Enquanto o caminhão, que percorre, indefinidamente, a estrada de Yveline,

45 LLANSOL, Gabriela. Um beijo dado mais tarde. Rio de Janeiro: 7 Letras, 2013, p. 37.

46 Cf. ARAÚJO, Cinara de. Biografia como método: a escrita da fuga em Maria Gabriela Llansol. 2008. 229f. Tese (Doutorado em Letras) - Faculdade de Letras, Universidade Federal de Minas Gerais, Belo Horizonte, 2008.

47 BLANCHOT. O livro por vir. p. 76.

48 "O interesse do diário é a sua insignificância. Essa é sua inclinação, sua lei. [...] Cada dia anotado é um dia preservado. [...] Assim, protegemo-nos do esquecimento e do desespero de não ter nada a dizer. [...] todos esses motivos faz do diário uma empresa de salvação: escreve-se para salvar a escrita, para salvar seu dia pela escrita, para salvar sua vida pela escrita, para salvar seu pequeno eu [...] ou para salvar o seu grande eu, dando-lhe um pouco de ar, e então se escreve para não se perder na pobreza dos dias ou, como Virginia Woolf, como Delacroix, para não se perder naquela prova que é a arte, que é a exigência sem limite da arte." BLANCHOT. O livro por vir. p. 273-4.

49 "[...] a necessidade de ser publicado - de atingir a existência exterior, a abertura para fora, a divulgação-dissolução de que nossas sociedades são o lugar - pertence à obra, com uma lembrança do movimento do qual vem, que ela deve prolongar incessantemente, que ela gostaria, entretanto, de ultrapassar radicalmente e ao qual dá um fim, de fato, por um instante, cada vez que é obra." BLANCHOT. O livro por vir. p. 363. 
dirigido pelo proletário, é o que leva o texto para o "exterior" - em determinado momento do filme, porém, o motorista admitiria não saber o que leva ${ }^{50}$.

$\mathrm{Na}$ análise feita por Adorno e Horkheimer, em Dialética do esclarecimento, acerca do episódio das sereias na Odisseia, os estudiosos afirmam que Ulisses foi o único a ouvir o canto dessas figuras mitológicas, porque era o patrão. Os demais, marujos, obedeceram à ordem de ter os ouvidos tapados para não ouvir o canto por vir, pois deveriam manter a embarcação em movimento, não podendo, assim, distrairse daquilo que é material. Da mesma forma, o motorista do filme de Duras, $O$ caminhão, não sabe o que transporta, afirma apenas que são fardos prontos, mas não Ihe interessa saber mais, pois compreende que, independente do que esteja carregando, não será algo de que possa desfrutar. É necessário que mantenha o automóvel em movimento. Blanchot também retoma a Odisseia para afirmar que a maneira como Ulisses enfrenta as sereias não é digna, uma vez que o faz pelo poder da técnica, joga "sem perigo com as potências irreais (inspiradas)" 51.

A crítica maior de Blanchot a Ulisses foi ter utilizado a arte para entreter-se. 0 pensador considera sublime o entreter-se com a obra literária desde que isso não vise nenhum objetivo, ou seja, aconteça por meio de um esquecimento daquilo que o mundo contemporâneo considera como essencial: o lucro - a arte que se transforma em produto. Ulisses, contudo, joga com a experiência artística ao reduzi-la a mera diversão, à técnica que nada transforma: "Aparentemente, fora dessa grande e ingênua pretensão [o do encontro de Ulisses com o canto insuficiente e sedutor das Sereias], nada mudou, e o relato parece, por sua forma, continuar respondendo à vocação narrativa ordinária" ${ }^{2}$. Com essa recusa, a partir dessa "ode transformada em episódio" ${ }^{3}$, o herói da Odisseia insurge-se contra as potências comandadas pela experiência da escrita literária.

50 "Voz em off de M.D.: / Ela ainda fala. Pergunta: / O senhor transporta o quê? / Voz em off de G.D.: / (Pausa.) / Não sei. Fardos prontos. / (Pausa.) / É para ser embarcado." DURAS. O caminhão. p. 8.

51 "É verdade, Ulisses as venceu, mas de que maneira? Ulisses, a teimosia e a prudência de Ulisses, a perfídia que the permitiu gozar do espetáculo das Sereias sem correr o risco e sem aceitar as consequências, aquele gozo covarde, medíocre, tranquilo e comedido, como convém a um grego da decadência, que nunca mereceu ser o herói da llíada, aquela covardia feliz e segura, aliás, fundada num privilégio que o coloca fora da condição comum, já que os outros não tiveram direito à felicidade da elite, mas somente ao prazer de ver seu chefe se contorcer de modo ridículo, com caretas de êxtase no vazio, direito também de dominar seu patrão (nisso consiste sem dúvida, a lição que ouviam, o verdadeiro canto das Sereias para eles): a atitude de Ulisses, a espantosa surdez de que é surdo porque ouve, bastou para comunicar às Sereias um desespero até então reservado aos homens, e para fazer delas, por desespero, belas moças reais, uma única vez reais e dignas de suas promessas, capazes pois de desaparecer na verdade e na profundeza de seu canto." BLANCHOT. O livro por vir. p. 8.

52 BLANCHOT. O livro por vir. p. 7.

53 BLANCHOT. O livro por vir. p. 6. 
Do mesmo modo, os "fardos prontos" levados pelo motorista d'O caminhão são produtos culturais, padronizados, alienados e alienantes. Segundo Marguerite Duras sua escrita é aceita como literatura, mas sua obra cinematográfica é deslegitimada por aqueles que se autodenominam os "profissionais" do cinema. Dessa forma, levando em consideração as noções de cultura e arte, há de se questionar a compreensão desses "profissionais" sobre o cinema e a liberdade artística, ou, como propõe Blanchot, a licença artística a que se permitem. Ademais, é necessário pensar no cinema que "existe": talvez ele seja uma realização cultural e não artística, pois os denominados profissionais do cinema produzem filme, e, para Leyla Perrone-Moisés a palavra "produção" é "marcadamente materialista" 54.

A ideia de cultura é promover uma identidade coletiva, sendo, então, homogênea. A arte sugere singularidade, diversificação e, sobretudo, liberdade, já que não se constitui como poder. Diferente da cultura, a manifestação artística não porta um engajamento ideológico com a linguagem e não possui objetivos. A arte se faz a partir dela mesma. Contudo, não carrega nenhuma transcendência, nada de místico, não existindo, assim, para ser adorada: "É que a obra de arte [...] não tem função nenhuma, e, assim sendo, deixa no mundo espaços vazios, não funcionais. $O$ vazio sente-se, mas nunca se adora, é fundamentalmente divergente em relação a deus" ${ }^{\text {" }}$.

A obra de Marguerite Duras acontece na solidão e existe à exceção de tudo: absolutamente só, despovoada de toda sombra interior. À vista disso, pode-se considerar a existência da escritura durasiana com base em uma ex-istência, conforme Lacan - em um fora de qualquer alienação, porque, o que realmente importa é o que se subtrai desses pontos, ou seja, o que "resta sem resto: a letra" ${ }^{56}$, haja vista o papel do caminhão na obra durasiana: levar o texto em direção à luz, ao exterior, a um real - cuja única possibilidade e exigência é a de escrever - ou, conforme o afirma Ruth Silviano Brandão, a de escreviver. ${ }^{57}$

Como proposto pelo "Quarto Projeto", a obra em questão parte de um "amor de ordem geral" e que é o vivenciado pela mulher, personagem, sendo e estando esta

54 "Em economia, produção é a criação de bens e serviços capazes de suprir as necessidades materiais do homem. Produção implica quantidade de objetos e coletividade de produtores e consumidores. Não tem, portanto, qualquer conotação sobrenatural; é ainda mais terrena que a palavra invenção." MOISÉS, Leyla Perrone-. A criação do texto literário. In: Flores da Escrivaninha. Companhia das Letras, 2016. p. 101.

55 BLANCHOT. O livro por vir. p. 40.

56 BRANCO, Lucia Castello. Chão de letras: as literaturas e a experiência da escrita. Belo Horizonte: Editora UFMG, 2011, p. 26.

57 Cf. BRANDÃO, Ruth Silviano. A vida escrita. Rio de Janeiro: 7 Letras, 2006. 
sempre voltada ao exterior, em direção ao tudo - ao amor. Sendo assim, O caminhão é um filme que se sustenta sob a noção de fracasso: de uma imagem ausente, de uma escrita sem vestimentas - "pobre" - e realizado no desastre que habita a região da escrita. O amor opera, aí, pelo olhar dirigido tanto ao texto quanto à imagem e caminha de braços dados com a memória e o feminino - elementos faltosos, opacos, com os quais a autora constrói a estrada por onde passa o caminhão - este que configura o amor, que, sem ninguém dentro, carrega consigo e em si a escrita, o traçado de um itinerário, a letra.

\section{Considerações finais}

O caminhão, de Marguerite Duras, parte de um risco, do traço de uma experiência literária - de uma aventura rumo ao desconhecido. Por isso não busca o grande o público, foge da culturalização imposta pelo mercado, não sendo, dessa maneira, um objeto de consumo, pois o que se volta ao grande público visando o entretenimento acaba por relegar ao homem a pior condição imposta à vida animal: a domesticação. Dessa forma, quem usa a literatura, o cinema, a arte em geral, a fim de subjugar, o faz a partir de uma posição de poder pessoal e de grupo, que parte da cultura e não da arte, e desonra a memória daqueles que não a utilizam ou utilizaram, inclusive a retiram ou retiraram de um campo de poder ${ }^{58} \mathrm{~A}$ obra em questão trata, do mesmo modo, da memória e do feminino e daí o que ela institui são os limites ou o abismo da linguagem: "o excesso linguageiro da escrita feminina. Porque se a mulher goza 'a mais', excede o fálico e vai gozar além, [...] [num] movimento excessivo, ruptor e irruptivo de ir além de si mesma"59. O poder delimita, por isso a escrita feminina o nega. A sua lógica é lacunar, "não toda", de gozo - já que há aí uma abolição do limite, embora pensada e instituída pela própria noção de limite, conforme observa Lucia Castello Branco.

O inacabamento de $O$ caminhão carrega toda a carga política presente na obra. A começar pela reunião "arbitrária, disparatada" entre o homem e a mulher - o masculino e feminino, o lógico e o aberto, entre os quais há a impossibilidade de um diálogo, haja vista as várias reticências que marcam a maior parte das falas e

58 Cf. LOPES, Silvina Rodrigues. Literatura, defesa do atrito. In.: A literatura como experiência. Belo Horizonte, Chão da Feira, 2012. p. 137-39.

59 BRANCO, Lucia Castello. A Traição de Penélope. São Paulo: Annablume, 1994, p. 118. 
divagações da mulher no texto, enquanto as orações ditas pelo motorista terminam com pontos finais ou silêncio - o homem quase não diz nada ${ }^{60}$.

Nesta mesma conversa, a mulher diz concordar com o homem acerca do destino da terra que a todo tempo "procura inverter a sua ordem": ela afirma que "toda revolução é impossível" ${ }^{\prime 1}$. Ou seja, numa sociedade em que não se assume nem a possibilidade de uma revolução ela acaba mesmo pertencendo ao campo do impossível. Por isso, como Duras (1977) afirma durante o filme, "que o mundo se arrebente, é a única política". Ou, como se deixa entrever no original, por meio da escolha da forma verbal - "Que le monde aille à sa perte, c'est la seule politique"62-, não apenas a forma do subjuntivo que está alinhado ao condicional e do faz de conta, todavia sublinha, também, "o movimento em direção à perda" e não simploriamente "a perda pura e simples", como pontua Blanchot acerca do desastre. Esse movimento é o movimento do próprio caminhão (texto/filme/depósito e nascente do imaginário) em seu traçado (seu itinerário e sua forma, seu sulco) rumo ao exterior, ao fora. Para a artista essa ruína já se iniciou, mas, conforme ela: "Tanto melhor. Tanto melhor. Quero dizer: não se crê em mais nada. Crê-se, é nisso que se crê: em mais nada. É uma nova alegria: não se crê em mais nada"63 - pois tudo agora pertence à ruína. Tal qual o seu desejo para o cinema, desejo de uma destruição total que o faça recomeçar do zero, afinal, é necessário que o mundo também fracasse, arruíne-se, a fim de que se faça surgir, daí, novas possibilidades para a alegria, a liberdade e a utopia.

Ademais, é nesse movimento de perder-se, do "aille à sa perte", que a obra permite uma confluência - ou seja, desloca-se em direção a um mesmo ponto de encontro: ao espaço em que Marguerite Duras afirma ser "o único lugar habitável", onde a convergência da imagem e da voz e/ou da imagem e do texto acontece devido a uma "materialidade contingente" ${ }^{64}$ que as une. Esse lugar é o do desobramento (desouvrement) proposto por Maurice Blanchot: ambiente noturno, próprio da arte, obscuro, subterrâneo, cujo deslocamento é em direção à ruína, à perda, ao desaparecimento - porém não aquele ao qual Hegel sentencia à arte, por achar que o cotidiano prosaico da sociedade anularia qualquer possibilidade de poesia. Para

60 "Voz em off de M.D.: / É aí que ela ia começar a falar. / Falar do que ela vê, exteriormente. / Ela diria: quantas coisas para ver... / De tal forma... / Extravasamos... não acha? / Ele não responde." (DURAS, $O$ caminhão. p. 14.

61 DURAS. O caminhão. p. 15.

62 DURAS. Le Camion. p. 25.

63 DURAS. O caminhão. p. 87.

64 DURAS. Nathalie Granger suivi de La femme du Gange. Paris: Gallimard, 1993, s/p. 
Blanchot (2011), o filósofo alemão possuía uma visão humanista da arte que fazia dela uma "atividade" no mundo a colaborar com a "obra humana" em geral e não uma "paixão inútil". Blanchot afirma que a arte é inútil para o mundo e para si mesma, por se realizar "fora das obras medidas [...] no movimento sem medida da vida". Dessa forma, ela "retira-se para o mais invisível e o mais interior, para o ponto vazio da existência onde se abriga a sua soberania na recusa e na superabundância da recusa"65. Portanto, o artista que verdadeiramente se dedica à obra de arte, o faz em busca de sua essência e não de um poder calculado por sua utilidade. Pois, conforme Blanchot, a essência da arte destina-se a si mesma, não se exaltando a valores terrenos, se subordinando ao trabalho real no mundo ou à preocupações estéticas. Do mesmo modo, a leitura realizada por Duras e Depardieu, encerrados na câmara escura, e o itinerário feito pelo caminhão, encaminham a obra rumo ao seu desaparecimento - "único lugar habitável”: ela mesma, seu próprio destino.

65 BLANCHOT. O espaço literário. p. 234. 


\section{Referências bibliográficas}

ANDRADE, Paulo de. O cinema sem imagens. In.: Aletria, Revista de Estudos de Literatura, Belo Horizonte, n.8, dez. 2001. (Literatura e cinema). p. 109-115.

ARAÚJO, Cinara de. Biografia como método: a escrita da fuga em Maria Gabriela Llansol. 2008. 229f. Tese (Doutorado em Letras) - Faculdade de Letras, Universidade Federal de Minas Gerais, Belo Horizonte, 2008.

BLANCHOT, Maurice. A escrita do desastre: fragmentos caídos de um texto ardente. Trad. João Rocha. In.: Revista Em Tese, v. 21, n. 2. Belo Horizonte: UFMG, Mai. Ago./2015, p. 147, 151.

. O espaço literário. Trad. Álvaro Cabral. Rio de Janeiro: Rocco, 2011.

. O livro por vir. Trad. Leyla Perrone-Moisés. São Paulo: Martins Fontes, 2005.

BRANCO, Lucia Castello. A Traição de Penélope. São Paulo: Annablume, 1994.

. Chão de letras: as literatura e a experiência da escrita. Belo Horizonte: Editora UFMG, 2011.

BRANDÃO, Ruth Silviano. A vida escrita. Rio de Janeiro: 7 Letras, 2006.

DELEUZE, Gilles. Crítica e Clínica. Trad. Peter Pál Pelbart. São Paulo: Editora 34, 2011.

DURAS, Marguerite. Le Camion. Paris: Les Éditions de Minuit, 2017.

. Escrever. Trad. Rubens Figueiredo. Rio de Janeiro: Rocco, 1994.

. Nathalie Granger suivi de La femme du Gange. Paris: Gallimard, 1993.

. Os olhos verdes. Crônicas publicadas em Cahiers du Cinéma. Trad. Heloisa Jahn. Rio de Janeiro: O Globo, 1988.

. O caminhão. Rio de Janeiro: Editora Record, 1977.

. O caminhão. [Filme-vídeo]. Produção e direção de Marguerite Duras. França, 1977. DVD, 76 min. Vídeo.

DURAS, Marguerite, GAUTHIER, Xavière. Boas falas: Conversas sem compromissos. Rio de Janeiro: Editora Record, 1974.

GREENAWAY, Peter. Cinema: 105 anos de texto ilustrado. In.: O cinema encilopédico de Peter Greenaway. São Paulo: Unimarco editora, 2004, p. 11-16.

LLANSOL, Gabriela. Um beijo dado mais tarde. Rio de Janeiro: 7Letras, 2013.

LOPES, Silvina Rodrigues. Literatura, defesa do atrito. In.: A literatura como experiência. Belo Horizonte, Chão da Feira, 2012. p. 137-39. 
lara rodrigues silva | a experiência literária em o caminhão, de marguerite duras

MOISÉS, Leyla Perrone-. A criação do texto literário. In: Flores da Escrivaninha. Companhia das Letras, 2016. p. 100-110.

Recebido em 01.08.2019. Aceito para publicação em 01.11.2019. (C) 2019 Lara Rodrigues Silva. Esse documento é distribuído nos termos da licença Creative Commons Atribuição-NãoComercial 4.0 Internacional (http://creativecommons.org/licenses/by-nc/4.0/deed.pt_BR) 